\title{
ТОЧНОСТ НА ЛЕКАРСКИТЕ ИЗВЕШТАИ ЗА ПРИЧИНА НА СМРТ ОД КАРДИОВАСКУЛАРНИ БОЛЕСТИ ВО БОЛНИЦА ОД СЕКУНДАРНА ЗДРАВСТВЕНА ЗАШТИТА
}

\author{
Наташа Петковиќ 1, Весна Велиќ Стефановска 2, Ирена Ефтимовска Рогач 1, Наташа \\ Ефимовска Отовиќ ${ }^{1}$, Ана Донева ${ }^{1}$, Наташа Ставрева

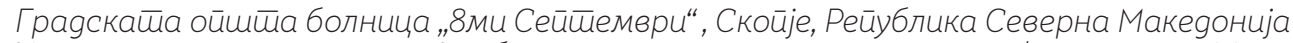

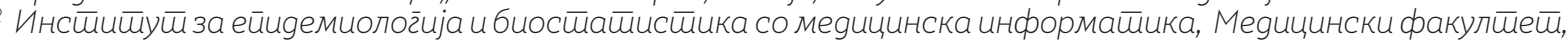

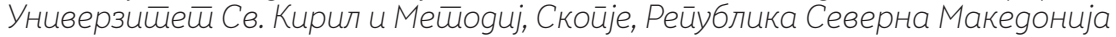

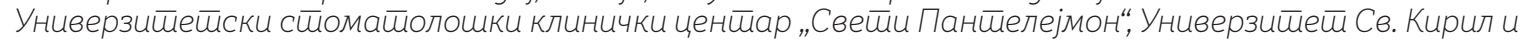 \\ меш̄оguj, Скойје, Реӣублика Северна Макеgонија
}

\begin{abstract}
Цитирање: Петковиќ Н, Велиќ Стефановска В, Ефтимовска Рогач И, Ефимовска Отовиќ Н Донева А, Ставрева Н. Точност на лекарските извештаи за причина на смрт од кардиоваскуларни болести во болница од секундарна здравствена заштита. Арх Ј Здравје 2019;11(2): 26-33

Клучни зборови: ЛИПС, точност, кардиоваскуларен морталитет, МКБ10,

*Кореспонденција: Наташа Петковиќ, Град ската општа болница „8ми Септември“, Скопје Република Северна Македонија, E-mail gramatnikovska@yahoo.com

Примено: 4-мар-2019; Ревидирано: 17-мај-2019; Прифатено: 20-мај-2019; Објавено: 15-јун-2019

Печатарски права: 2019 Наташа Петковиќ. Оваа статија е со отворен пристап дистрибуирана под условите на нелокализирана лиценца, која овозможува неограничена үпотреба, дистрибуција и репродукција на било кој медиум доколку се цитираат оригиналниот(ите) автор(и) и изворот. Конкурентски интереси: Авторот изјавува дека нема конкурентски интереси.
\end{abstract}

\section{Извадок}

Морталитетната статистика по причини за смрт е основен показател на здавствената состојба на населението во една земја. Нејзината валидност во целост е базирана на точноста на Лекарските извештаи за причина на смрт (ЛИПС) што претставуваат нејзин основен извор на податици. Цел на ова истражување е да се утврди точноста на лекарските извештаи со впишано КВ3 (I10 - I50) како основна причина за смрт во Градската општа болница „8ми Септември“ во Скопје. Материјал и методи: Истражувањето представува квантитативна аналитичка студија на пресек имплементирана во Градската општа болница „8ми Септември“ - Скопје во периодот од јануари 2015 до декември 2016 година. Во истражувањето беа анализирани ЛИПС-овите кои согласно МКБ10 беа со впишано КВ3 (I10 - I50) како основна причина за смрт. Опфатени беа 121 пациент на возраст од 24 до 84 години кои починале во периодот 0 - 28 дена од хоспитализацијата и тоа независно од полот и другите социо-демографски карактеристики. Анализата на точноста на ЛИПС-овите, беше направена согласно стандардизиран образец од MONICA проектот. Резулта-

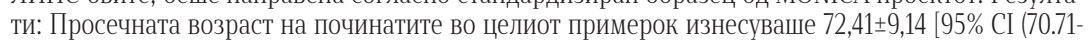
$74,11)]$ години. Точно пополнети ЛИПС-ови биле 67 (56,3\%), неточно 22 (18,5\%) и делумно точно 30 (25,2\%). Нема сигнификантна асоцијација (p>0,05) меѓу полот на испитаниците и точноста на впишување на примарната причина за смрт. Утврдена е сигнификантно $(p<0,05)$ поточно е впишана секундарна причина за смртта кај лицата од машки пол. Заклучок: Со извесна лимитација поради малиот број на случаи истражувањето укажува на неусогласеност помеѓ податоците превземени од болничката документација и причината за смрт впишана во ЛИПС-овите. Постои реална потреба да се превземат адекватни мерки за подобрување на квалитетот на ЛИПС.

\section{CLINICAL SCIENCE}

\section{ACCURACY OF DEATH CERTIFICATION FROM CARDIVASCU- LAR MORTALITY IN SECONDARY CARE HOSPITAL}

Natasha Petkovikj¹, Vesna Velikj Stefanovska², Irena Eftimovska Rogach ${ }^{1}$, Natasha Eftimovska Otovikj ${ }^{1}$, Ana Doneva ${ }^{1}$, Natasha Stavreva ${ }^{3}$

\section{City General Hospital "8th September", Skopje, Republic of North Macedonia}

2 Institute for Epidemiology and Biostatistics with Medical Informatics, Medical Faculty, University Sts Ciril and Methodius, Skopje, Republic of North Macedonia

3 University Stomatology Clinic Centre "Saint Panteleimon", Skopje, Republic of North Macedonia

Citation: Petkovikj N, Velikj Stefanovska V, Eftimovska Rogach I, Eftimovska Otovikj N, Doneva A, Stavreva N. Accuracy of death certification from cardivascular mortality in secondary care hospital. Arch Pub Health 2019; 11 (2): 26-33

Key words: death certificates, accuracy, cardiovascular mortality, ICD10, MONICA project.

*Correspondence: Natasha Petkovikj, City General Hospital "8th September", Skopje, Republic of North Macedonia. E-mail: gramatnikovska@yahoo. com

Received: 4-Mar-2019; Revised: 17-May-2019; Accepted: 20-may-2019; Published: 15-Jun-2019 Copyright:@ 2019. Natasha Petkovikj. This is an open-access article distributed under the terms of the Creative Commons Attribution License, which permits unrestricted use, distribution, and reproduction in any medium, provided the original author(s) and source are credited.

Competing Interests: The author have declared that no competing interests

\section{Abstract}

Mortality statistics for causes of death is a basic indicator of the state of health of the population in one country. Its validity is entirely based on the accuracy of Death Certificates that is primary source of data. The purpose of this research is to determine the accuracy of Death Certificates with the inscription (I10 - I50) according to the as the main cause of death in the City general hospital "8th of September" in Skopje. Material and Methods: The survey is a crossectional study implemented in the City general hospital "8th September" - Skopje in the period from January 2015 to December 2016. The study analyzed the Death Certificates that according to ICD10 were inscribed with the I10 - I50 a codes as the main cause of death. There were 121 patients aged 24 to 84 who died in the period 0-28 days of hospitalization, regardless of sex and other socio-demographic characteristics. The analysis of the accuracy of the Death Certificates was done in accordance with the standardized form of the MONICA project. Results: The average age of the deceased in the entire sample was 72.41 \pm 9.14 [95\% CI (70.71-74.11)] years. Fully filled Death Certificates were 67 (56.3\%), incorrect 22 (18.5\%) and partly accurate $30(25.2 \%)$. There is no significant association ( $p>0.05)$ between the sexes of the examinees and the accuracy of the inclusion of the primary cause of death. Significantly $(p<0.05)$ more accurately inscribed secondary cause of death in males was found. Conclusion: With a certain limitation of the small number of cases, the research points to the inconsistency between the data taken from the hospital documentation and the cause of death written in the Death Certificates. There is a real need to take adequate measures to improve the quality of the Death Certificates. 


\section{Вовед}

Морталитетната статистика овозможува континуиран мониторинг на здравјето на населението. Лекарските извештаи за причина на смрт (ЛИПС) се драгоцена алатка и важен извор на податоци за морталитетната статистика како на национално така и на локално ниво. Придобивките од ЛИПС-овите се бројни и вклучуваат доказ за ненасилна смрт, следење на здравјето на генералната популација, планирање на здравствената заштита на населението и одредување на приоритетите за превенција на болестите. Точноста на податоците во ЛИПС-овите е елементарна и во поставувањето на голем број клинички студии ${ }^{1,2,3}$.

И покрај научно признаената важност на ЛИПС-от, потполнувањето на овој образец во практика е нецелосно и со дискутабилна точност на впишаните податоци. Најчеста причина за ова е недоволно посветено внимание, не препознавањето на важноста од навременото и точно пополнување како и недоволниот тренинг на мртвопроверителите за начинот на пополнување на овој образец. Сето ова резултира со недоволно квалитетна база на податоци за причините за смрт, и лажна претстава за здравствените проблеми на популацијата ${ }^{4}$. На ниво на креатори на здравствна политика, недостатокот на релевантни податоци за причините за смрт неминовно резултира со погрешни одлуки во однос на здравствените приоритети.

Почетоците на регистрацијата на причините за смрт датираат од средината на 15-тиот век во централна Италија каде медицинската едукација и социјалната администрација биле понапредати споредено со останатиот дел на Европа. Во 16-тиот век формирани се здравствени одбори во Франција, Швајцарија и Холандија, но само како времени мерки за периоди на кризи. Почнувајќи од средината на 18-тиот век, националните цивилни системи за регистрација започнуваат со континуирано следење и статистика на новородени и починати. Во 1855 Американската Медицинска асоцијација (AMA) усвојува резолуција за превземање иницијатива за отворање канцеларии за регистрирање на виталните настани ${ }^{5}$.

Светската здравствена оганизација (C3O) заедно со нејзини партнер организации дефинираат правила и креираат водичи за кодирање на морталитетот и морбидитетот. Класификацијата на болестите е по систем на категории каде ентитетите на заболувањата се означуваат согласно етаблирани критериуми. Целта на меѓународната калсификација на болести и поврзани здравствени проблеми (МКБ) е да овозможи систематско забележување, анализа и интерпретација на морталитетот и морбидитетот во една земја. Нејзината глобална примена овозможува, во секој момент, да биде возможна споредба на морбидитетната и морталитетната статистика помеѓу земјите и регионите.

Со МКБ дијагнозите на болестите и другите здравствени проблеми се преведуваат во алфанумерички код што овозможува нивно лесно складирање и анализа. Досега се направени 10 ревизии на МКБ, а во тек е завршувањето на единаестата ревизија. Ревизиите на МКБ ги инкорпорираат предлозите на бројни специјалисти од различни области.

Точноста на ЛИПС-овите во различни земји е различна. На глобално ниво е утврдена точност на примарната дијаноза од 57,5\%, што претстваува релативно ниско ниво на точност. Согласно многу анализи, неточноста на овие податоци е честа карактеристика на земјите во развој $^{1,2}$.Ова особено се должи на дијагностичките проблеми дури и во земји во кои се изведува задоволитен број на аутопсии ${ }^{4}$. За жал, во Р.Македонија аутопсиите најчесто се изведуваат при сомнителна или насилна смрт. Голем проблем за спроведување на аутопсиите се ниската здравствена култура и верските убедувања. Дел од вината лежи и во системскиот недостаток на протокол за начинот на разговор со семејството и потребниот степен на упорност во убедувањето на семејствата да дадат одобрување за аутопсија. Ова е посебно важно кај недоволно јасни случаи и при ненадејна смрт. При пополнувањето на ЛИПС-от, дистинкцијата помеѓу одредувањето на примарната и секундарната 
причина за смрт, како и за начинот на настапување на смртта, се главната задача на мртвопроверителот.

Иако на генерално ниво постојат големи познавања за состојбата со кардиоваскуларните заболувања - КВЗ особено акутниот миокардијален инфаркт - АМИ и цереброваскуларниот инсулт - ЦВИ, искуствата од практиката укажуваат на полемики околу точноста на податоците. Поради тоа С3О го започнала мултинационалниот мониторинг на трендовите и детерминантите на кардиоваскуларните заболувања - МОНИKA проект (Multinational MONItoring of Trends and determinants in CArdiovacular disease - MONICA Project). Овој проект овозможил подобро разбирање на етиологијата на болеста и нејзината развојна тенденција на ниво на популација.

MONICA проектот бил имплементиран во период од десетина години и тоа од раните 80-ти до средината на 90 -тите години на минатиот век. Студијата се карактеризирала со добро опишани методи за добивање податоци со висок квалитет. Била спроведена низ различни центри во вкупно 21 земја при што биле мониторирани околу 13 милиони луѓе ${ }^{1}$ Анализата укажала на вкупно регистрирани 166,000 пациенти со миокардни инфарктии при што повеќе од 300000 мажи и жени биле следени за нивниот кардиоваскуларен ризик и многу други здравствени податоци ${ }^{6,7}$.

Цел на ова истражување е да се утврди точноста на лекарските извештаи со впишано KB3 (I10 - I50) како основна причина за смрт во Градската Општа Болница „8ми Септември“ - Скопје во периодот 2015/16 година.

\section{Материјал и методи}

Истражувањето представува квантитативна аналитичка студија на пресек имплементирана во Градската општа болница „8ми Септември“ - Скопје во периодот од јануари 2015 до декември 2016 година. Согласно поставените инклузиони и ексклузиони критериуми беше направена селекција на Лекарските извештаи за причина на смрт - ЛИПС во кои според МКБ10, беше впишано KB3 (I10 - I50) како основна причина за смрт. За проверка на секој од ЛИПС-овите беше анализирана соодвентната хоспитална медицинска документација. Истражувањето беше одобрено од Етичката комисија на Медицинскиот факултет при Универзитетот “Св. Кирил и Методиј“ во Скопје.

Во истражувањето беа вклучени ЛИПСови кои, согласно МКБ10, беа со впишано KB3 (I10 - I50) како основна причина за смрт и тоа кај пациенти на возраст од 24 до 84 кои починале во периодот 0 - 28 дена од хоспитализацијата и тоа независно од полот и другите социо-демографски карактеристики. Од истражувањето беа исклучени ЛИПС-овите на лицата кои биле донесени починати во болница, а за кои, според МКБ10, било впишано KB3 (I10 - I50) како основна причина за смрт. Како шифри кои не се од интерес за истражувањето беа исклучени оние кои се однесуваат на ревматски срцеви заболувања, цереброваскуларните заболувања, и периферни артеријски и венски заболувања.

Анализата на точноста на ЛИПС-овите, беше направена согласно стандардизиран образец од MONICA проектот $(5,14,15)$ при што беа опфатени аспекти како: а) демографски карактеристики (серијски број, возраст, пол,); б) клинички преглед при прием (срцев застој при доаѓање во болница, ресусцитација од кардиак арест кој настанал во болница, првиот систолен притисок измерен пред започнување на медицинскиот третман, пулс итн.); в) ЕКГ промени (СТ елевација, СТ депресија, еволуција на Ку забец, ЕКГ промени во предните одводи V1-V5); г) престој во коронарна единица (престој и број на денови во коронарна единица) и д) место на настанување на смртта.

Во ЛИПС-овите беше анализирана точноста на примарната причина за смрт, на секундарната причина за смрт и на начинот на настанување на смртта. Беа користени следните дефиниции: а) примарна причина - повреда или болест која го започнува следот на настани кои доведуваат до смрт и е класифицирана по International Classification of Diseases (ICD) систем; б) секундарна причина- непосредната причина(и) за смрт која/кои се резултат на примарната причина за смрт; и в) начин на настанувањена смр- 
тта - класификација на смртта базирана на типот на состојбата која ја предизвикала смртта и околностите под кои се појавила (пример: природна, хомицидна, суцидна).

Оценувањето на точноста на ЛИПС-овите беше евалуирана како: а) точна - кога причината напишана во ЛИПС соодвествува со податоците добиени од болничката историја на болеста; б) неточна - податоците од историјата укажуваат на водечка причина за смрт која не е впишана во ЛИПС туку е ставена друга дијагноза или неадекватна дијагноза; и в) дискутабилна односно делумно точна - кога кај пациентот има две или повеќе водечки дијанози кои можат сами по себе да доведат до смртен исход и не може со сигурност да биде утврдено која од нив е водечка причина за смртта.

Податоците беа обработувани во IBM SPSS Statistics 20. За анализа на атрибутивните (квалитативни) серии беше користен коефициент на односи, пропорции и стапки, а истите беа прикажани како апсолутни и релативни броеви. Квантитативните серии беа анализирани со употреба на мерките на централна тенденција (просек, медијана, минимални и максимални вредности), како и со мерки на дисперзија (стандардна девијација, стандардна грешка). Дистрибуцијата на фреквенциите на нумеричките варијабли беше утврдувана со ShapiroWilk W test. Сигнификантноста на разликата помеѓу две пропорции беше анализирана со Difference test. Chi square exact two tailed test и Fisher-FreemanHalton exact test беа користени за утврдување на асоцијацијата меѓу одредени белези во групата испитаници. Кај нумеричките серии со неправилна дистрибуција на фреквенции беше користен Mann Whitney U test. За утврдување на статистичка значајност беа користени two way tests со ниво на сигнификантност од $\mathrm{p}<0,05$.

\section{Резултати}

Во периодот од јануари 2015 до декември 2016 година, во Градската општа болница „8ми Септември“ - Скопје, биле регистрирани вкупно 121 ЛИПС на лица со впишано KB3 (I10 - I50) како основна причина за смрт. Кај ниту еден од починатите пациенти не е направена аутопсија. Сите починати пациенти се починати од природна смрт.

Просечната возраст на починатите лица воцелиотпримерок изнесувала $72,41 \pm 9,14$ $[95 \%$ CI $(70.71-74,11)]$ години со минимална односно максимална возраст од 40 v.s. 83 години. Од машки односно од женски пол биле консеквентно 64 (52,9\%) v.s 57 (47,1\%) лица со однос помеѓу половите од 1:1,12. За $p>0,05$, анализата не укажа на сигнификантна проценуална разлика во застапеноста на половите (Difference test: Difference 3,16\% [95\% CI (-6,71-18,06)]; Chi-square $=0,811 ; \mathrm{df}=1 \mathrm{p}=0,368$ ).

Починатите лица од машки пол биле со просечна возраст од 70,62 $\pm 9,91$ [95\% $\mathrm{CI}(68,22-72,97)]$, и со минимална односно максимална возраст од 42 v.s 83 години. Кај починатите лица од женски пол просечната возраст изнесувала 74,42 $\pm 7,81$ [95\% CI(72,16-76,23)], со минимална, односно максимална возраст од 40 v.s. 83 години. Утврдена е сигнификантна разлика помеѓу просечната возраст на двата пола во прилог на сигнификантно повисока возраст кај починатите лица од женски пол (Mann-Whitney U Test: $\mathrm{Z}=2,125 ; \mathrm{p}=0,034)$.

Примарната причина повреда или болест која го започнува следот на настани кои доведуваат до смрт била пополнета во 119 (98,35\%) ЛИПС-ови (Табела 1). Впишувањето на примарната причина било оценето како: а) точно кај 72 (60,5\%); б) неточно кај 20 (16,8\%), и в) дискутабилно односно делумно точна кај 13 (11\%) од ЛИПС-овите. Нема сигнификантна асоцијација меѓу полот на испитаниците и точноста на впишување на примарната причина за смрт (Pearson Chisquare $=3,604, \mathrm{df}=2, \mathrm{p}=0,165)$.

Секундарната причина т.е. непосредната причина(и) за смрт која/кои се резултат на примарната причина за смрт била пополнета во 98 (80,99\%) ЛИПС-ови (Табела 1). Впишувањето на секундарната причина било оценето како: а) точна кај 66 (67,3\%); б) неточна кај 13 (13,3\%), и в) дискутабилна односно делумно точна кај 19 (19,4\%) од ЛИПС-овите. Утврдена е сигнификантна асоцијација меѓу полот на испитаниците и точноста на впишување на секундарната причина за 
смрт (Fisher-Freeman-Halton exact test: $\mathrm{p}=0,002)$ во прилог на сигнификантно поточно впишана секундарна причина за смрт кај лицата од машки пол.

Евалуацијата на вкупната точност на ЛИПС-овите базирана на точноста на впишувањето на примарната и секунраната причина за смрт укажа дека точ- ни биле 67 (56,3\%), неточни 22 (18,5\%) и делумно точни 30 (25,2\%). Нема сигнификантна асоцијација помеѓу полот на испитаниците и точноста на ЛИПС-оците со впишано KB3 (I10 - I50) како основна причина за смрт (Pearson Chisquare $=2,734, \mathrm{df}=2, \mathrm{p}=0,255)$.

Табела 1. Анализа на точноста на ЛИПС-овите според пол

\begin{tabular}{|l|c|c|c|}
\hline \multirow{2}{*}{ Точност на ЛИПС } & \multicolumn{2}{|c|}{ Пол } & \multirow{2}{*}{ Вкупно } \\
\cline { 2 - 3 } & мажи & жени & \\
\hline ПРИмАРНА ПРИЧИНА - Pearson Chi-square=3,604, df=2, p=0,165 \\
\hline Точен & $41(65,1 \%)$ & $31(54,4 \%)$ & $72(60,5 \%)$ \\
\hline Неточен & $12(19,0 \%)$ & $8(14,3 \%)$ & $20(16,8 \%)$ \\
\hline делумно точен & $10(15,9 \%)$ & $17(30,4 \%)$ & $27(22,7 \%)$ \\
\hline СЕКУНДАРНА ПРИЧИНА - Fisher-Freeman-Halton ехасt test: p=0,002* \\
\hline Точен & $41(74,5 \%)$ & $25(58,1 \%)$ & $66(67,3 \%)$ \\
\hline Неточен & $10(18,2 \%)$ & $3(7,0 \%)$ & $13(13,3 \%)$ \\
\hline делумно точен & $4(7,3 \%)$ & $15(34,9 \%)$ & $19(19,4 \%)$ \\
\hline ВКУПНА ТОчНОСТ - Реarson Chi-square=2,734, df=2, p=0,255 & \\
\hline Точен & $38(60,3 \%)$ & $29(51,8 \%)$ & $67(56,3 \%)$ \\
\hline Неточен & $13(20,6 \%)$ & $9(16,1 \%)$ & $22(18,5 \%)$ \\
\hline делумно точен & $12(19,0 \%)$ & $18(32,1 \%)$ & $30(25,2 \%)$ \\
\hline
\end{tabular}

\section{Дискусија}

Анализата на лекарските изваштаи на причина за смрт представува едно од најстарите и најекстензивните следења на здравствената состојба на популацијата. Најчесто сите морталитетни статистики се однесуваат на непосредната причина за смрт, занемарувајќи ги предходните причини кои довеле до непосредната причина за смрт. Во оваа студија беа анализирани и примарните и секундарните дијагнози. И во двата случаи има речиси идентична точност. Забележана е сигнификантно поголема точност при пополнувањето на секундарната причина за смрт кај испитаниците од машки пол.

По однос на дискутабилните дијагнози -пронајдени се вкупно 8 починати каде причината за смрт е дискутабилна. Најчесто се работи за пациенти со хронична обструктивна белодробна болест кои развиле срцева слабост. Актуелната хоспитализација, пред се, се должи на егзацербација на ХОББ и терапијата е доминанатно насочена кон третирање на ова заболување. При пополнување на ЛИПС-от лекарите се одлучиле да ја стават срцева слабост како основна дијагноза. Исто така, како дискутабилни се ставени случаи кај кои постои изразена анемија за која нема утврдено причина (најверојатно дигестивно крварење) и е вршена субституција со крвни деривати. Акутната или акутна врз хронична бубрежна слабост можела да доведе до смртен исход сама за себе. Нотирани се и два случаи на илеус кој најверојатно довел 
до смртен исход но впишана е срцева слабост како причина за смрт. Горенаведеното упатува дека кога постојат мултипли коморбидитети лекарите се одлучуваат да стават кардиоваскуларно заболување како основна причина за смрт. Ова доведува до податоци за лажно зголемен морталитет од КВЗ. Сите анализираните ЛИПС-ови не содржат ICD-10 код.

За време на формалната медицинска едукација нема фокусирана обука за пополнување на ЛИПС. Иако поголем дел од лекарите се соочуваат со задачата да пополнуваат ЛИПС, најчесто тие за првпат пополнуваат ваков образец кога ќе се соочат со починат пациент. Голем проблем представува несериозниот пристап кон пополнувањето, кое се смета за административна процедура за издавање на документ за погреб на починатиот. При тоа постои отсуство на свесност на одговорниот лекар за потребата да се навлезе подлабоко во механизмот на настанување на смртта и непосредната причина како и важноста од точноста на впишаните податоци. Согласно ова, неопходна е континуирана медицинска едукација во оваа област во форма на годишни курсеви со интерактивни работилници за пополнување на ЛИПС како би се подобрила точноста ${ }^{8,9,10,11,12,13}$.

Некои студии сугерираат дека ваков едукационен напор може да биде успешен 14,15,16,17 особено ако инетрвенцијата е интерактивна ${ }^{18}$. Други студии покажуваат конфликтни резултати. И покрај итервенцијата и формалниот тренинг кај студентите во Универзитетот Лајкестер во Обединетото кралство само 55\% од ЛИПС-овите го задоволуваат минимално прифатливиот стандард 19. За кардиоваскуларните болести утврдена е севкупна точност од 65\%. Но кај коронарната артеријска болест точноста достигнува 74.0\% 20. Користејќи ги податоците од Фрамингамската студија (Framingham Heart Study), Lloyd-Jones et al. се обиделе да ја утврдат точноста на ЛИПС-овите кај кодовите каде коронарната артеријска болест е ставена коко основна причина за смрт. Тие утврделе дека во ЛИПС-овите биле прикажани 24.3\% повеќе починати од коронарна артеријска болест споредено со фактичката состојба ${ }^{21}$. Во друга студија било утвредно дека во ЛИПС-овит од 242 починати вкупно 51.2\% биле кодирани за коронарна артеријска болест кај од кои кај 9\% истражувачите не можеле да ја утврдат точната причина за смрт 22. Слични податоци се добиваат и во студијата за точност на кодирањето во Бахреин каде е утврдено несогласување на податоците кај 10-30\% од починатите од коронарна артеријска болест ${ }^{23}$.

Во Саудијска Арабија е утврдена неточност на впишаната причина за смрт кај 80.3\% од анализираните ЛИПС-ови за вкупен моралитет. Вкупно 46,7\% од грешните ЛИПС-ови биле со впишани заболувања на кардиваскуларниот систем 1.

Податоците добиени од нашата студија се слични со добиените резултати од студија спроведена во болница во Ланкастер каде била утврдена совкупна точност од $56,3 \%$.

Дали е потребна аутопсија за да се добијат податоци со поголема точност? Неспорно е дека аутопсијата е многу значајна процедура за точно утврдување на причината за смрт 24,25,26,27. Сепак, многубројни се студиите според кои, во најголемиот број ситуации, оптималните клинички податоци даваат добар увид во здравствената состојба на пациентот што му овозможува на обученото лице со голема веројатност за точност да го изврши шифрирањето.

\section{Заклучок}

Процесот на идентификација на непосредната причина за смрт базирано само на клинички податоци е со лимитирана точност. Сепак, независно од овој факт, морталитетната статистика за кардиоваскуларните заболувања останува основа во дизајнот на многу епидемиолошки студии и клиничките истражувања во оваа област и пошироко. Резултатите од оваа студија укажуваат дека ЛИПС-вите со впишано KB3 (I10 - I50) како основна причина за смрт во Градската општа олница „8ми Септември“ - Скопје во голем дел не ги задоволуваат критериумите за 
точност. Ова ја наметнува неопходната потреба за генерално решавање на овој проблем. Здруженијата на кардиолози треба критички да се однесуваат кон потребата за поголема точност на морталитетната статистика од оваа област.

Земјите во развој треба да го следат примерот на развиените земји во настојувањата за што е можно поголема точност на морталитетните податоците. Предлагаме дефиниран унифициран приод на докторите во пополнувањето на ЛИПС-овите; едукација во додипломската настава како и тренинг на дипломираните доктори на медицина за пополнување на ЛИПС-овите и одредување на точната причина за смрт; употреба на ICD-10 кодирањето; како и имплементирање компјутеризирано наместо мануелно пополнување на ЛИПС-овите. Останува потребата од зголемување на бројот на медицински аутопсии кај пациенти починати во болничките установи.

\section{Референци}

1. Alsaleh S, Al-Hussein M, Almajid K. S, Alsani Z. S. Assessment of the accuracy of death certification at two referral hospitals. J Fam Community Med 2008;15:43-50.

2. Sibai AN, Nuwaihid I, Beydouin M, Chaaya M. Inadequacies of Death Certification in Beirut: Who is Responsible? Bull World Health Organ 2002; 80: 555-561.

3. Swift B. and West K. Death Certification: an Audit of Practice Entering the 21st Century. J Clin Pathol 2002; 55: 275-279.

4. Moussa, M.A. et al. Reliability of Death Certificate Diagnosis. J Clin Epidemiol1990; 43 (21): 1285-1295.

5. Moriyama IM, Loy RM, Robb-Smith AHT. History of the statistical classification of diseases and causes of death. Rosenberg HM, Hoyert DL, eds. Hyattsville, MD: National Center for Health Statistics. 20118.

6. Grant, T.M., Powell, S.R. and Steinbeck, B. Preparing for ICD-10-PCS. For the Record, 2002; 14 (25):1-4.
7. U. Keil. The Worldwide WHO MONICA Project: Results and Perspectives. Gesundheitswesen. 2005; 67Suppl 1:S38-45.

8. Knight, B. Medical Aspects of Death. In: Simpson's Forensic Medicine, 11th edition. Knight B., Arnold, London; 1997.

9. National Association of Medical Examiners. Writing Cause of Death Statements - Basic Principles, Sept. 3, 2005.

10. Centers for Disease Control and Prevention's National Center for Health Statistics. Physicians' Handbook on Medical Certification of Death, 2003 revision. Hyattsville, Md: US Department of Healthand Human Services; [DHHS publication No. (PHS) 20031108].

11. Lakkireddy DR, Basarakodu KR, Vacek JL, et al. Improving death certificate completion: a trial of two training interventions. J Gen Intern Med 2007; 22:544-548.

12. Villar J, Pérez-Méndez L. Evaluating an educational intervention to improve the accuracy of death certification among trainees from various specialties. BMC Health Serv Res 2007;7:183.

13. Izegbu MC, Agboola AOJ, Shittu LAJ, Akiode O. Medical certification of death and indications for medico-legal autopsies: The need for inclusion in continue medical education in $\mathrm{Ni}$ geria. Scientific Research and Essay. 2006;1(3):061-4.

14. Pritt BS, Hardin NJ, Richmond JA, Shapiro SL. Death Certification Errors at an Academic Institution. Arch Pathol Lab Med 2005;129:14769.

15. Abos R, Perez G, Rovira E, Canela J, Domenech J, Bardina JR. A pilot program to improve causes of death certification in primary care of Catalonia, Spain. Gac Sanit 2006; 20(6):450-456.

16. Myers KA, Farquhar DR. Improving the accuracy of death certification. CMAJ 1998;158(10):1317-1323. 
17. Degani AT, Patel RM, Smith BE, Grimsley E. The effect of student training on accuracy of completion of death certificates. Med Educ Online 2009;14:17

18. Lakkireddy DR, Basarakodu KR, Vacek JL, Kondur AK, Ramachandruni SK, Esterbrooks DJ, et al. Improving death certificate completion: a trial of two training interventions. J Gen Intern Med 2007;22(4):544-548.

19. Cirera SL, Martinez LC, Contreras GJ, Navarro SC. Learning and satisfaction in the workshops of pre- and post-graduate medicine for the improvement of the accuracy of certifications of causes of death 19921996. Rev Esp Salud Publica 1998; 72(3):185-195

20. Swift B, West K. Death certification: an audit of practice entering the 21st century. J Clin Pathol 2002; 55(4):275-279.

21. Jedrychowski W., Mróz E, Wiernikowski A, Flak E. Validity study on the certification and coding of underlying causes of death for the mortality statistic. PLoS One 2012; 7(2): e31427.

22. Lloyd-Jones DM, Martin DO, Larson MG, Levy D. Accuracy of death certificates for coding coronary heart disease as the cause of death. Ann Intern Med 1998;129(12):1020-1026.

23. Al-Mahrous, R. Validity of death certificates for coding coronary heart disease as the cause of death in Bahrain. East Mediterr Health J 2000; 6(4):661-669.

24. Lee PN. Comparison of autopsy, clinical and death certificate diagnosis with particular reference to lung cancer. A review of the published data. APMIS Suppl. 1994;45:1-42.

25. Pinto Carvalho FL, Cordeiro JA, Cury PM. Clinical and pathological disagreement upon the cause of death in a teaching hospital: Analysis of 100 autopsy cases in a prospective study. Pathology International 2008;58(9):568-571
26. Ermenc B. Comparison of the clinical and post mortem diagnoses of the causes of death. Forensic science international 2000;114(2):117-119.

27. Cameron HM, McGoogan E. A prospective study of 1152 hospital autopsies: I. Inaccuracies in death certification. J Pathol 1981;133(4):273-283. 